\title{
Albanian Consumer Perception of Domestically Produced Goods: The Impact of Country of Origin and Consumer Ethnocentrism
}

\author{
Skender Brucaj \\ Faculty of Technology and Business, Bedër University College, Tirana, Albania \\ Email: sbrucaj@beder.edu.al
}

How to cite this paper: Brucaj, S. (2020). Albanian Consumer Perception of Domestically Produced Goods: The Impact of Country of Origin and Consumer Ethnocentrism. Open Journal of Business and Management, 8, 2545-2558.

https://doi.org/10.4236/ojbm.2020.86158

Received: July 27, 2020

Accepted: November 14, 2020

Published: November 17, 2020

Copyright ( 2020 by author(s) and Scientific Research Publishing Inc. This work is licensed under the Creative Commons Attribution International License (CC BY 4.0).

http://creativecommons.org/licenses/by/4.0/

\begin{abstract}
Nowadays, the rapid development of technology has revolutionized global business. These changes in computer and communication technologies have made it possible for businesses to directly reach customers anywhere in the world. Therefore, economies of many countries are based on international trade. The traditional way of dealing with costumers, markets and workplaces is not enough for today's institutions and business organizations to succeed in this century. The purpose of this research is testing the effect of country of origin (COO) on Albanian consumers purchasing preferences and to measure consumer ethnocentrism in Albanian market. This study tried to investigate the influence of $\mathrm{COO}$ and consumer ethnocentrism in a multi-dimensional context, taking the consideration for the effect of different factors such as price, brand cues and costumer experience in purchase decision of good in Albanian market. The hypotheses are examined with data assembled from 278 Albanian consumers. There were four product preferences attributes in survey questionnaire: product origin, brands, consumer experience and price. As result of study, the effect of ethnocentrism was found as important factor that affects Albanian consumer's product evaluations and their purchase intentions. In addition, in Albanian marketplace, country of origin has great impact regarding the evaluations of foreign goods.
\end{abstract}

\section{Keywords}

Country of Origin (COO), Consumer Behavior, Ethnocentrism

\section{Background}

Nowadays, the rapid development of technology has revolutionized global business. These changes in computer and communications technologies have made 
it possible for businesses to directly reach customers anywhere in the world. Therefore, economies of many countries are based on international trade. In the same time, globalization as a dynamic process stimulates economic growth, improves product quality and has increased competition among business organizations. The traditional way of dealing with costumers, markets and workplaces is not enough for today's institutions and business organizations to succeed in this century (Erixon, 2018). Many challenges face global business in the 21st century such as changing customer values and orientations, increase of global competitiveness, overpopulated society, political instability, environmental degradation, world poverty, educational problems and job creation (Ahmed \& D'Astous, 1993). Many business organizations are trying to identify the challenges in the global market, regardless of their size and age they have to rethink their organizational processes and methods. To be successful in the 21 st century, all business organizations have to be strongly customer focused. Therefore, in this globalized business environment, consumers are faced with different purchase choices from domestic products to foreign products (Alexandra \& Mazzocchi, 2007).

\subsection{Introduction of Albanian Market}

Since the collapse of communism after 1991, starting from low based closed economy inherited from past communism regime, Albania has faced the power of globalization and free international trade, by reducing quotas for foreign products the barriers for import of foreign goods disappeared (Doka, 2005). As effect of decrease in trade obstruction among different nations, Albanian consumers can choose to purchase their products from both domestically produced and imported ones, ranging from salt to computers and automobiles. This positive increase in achievement and development faced an economic turmoil in 1997. During this period, Albanian people lost more than 1 billion dollars of their savings due to collapse of several pyramid organizations. Pyramid schemes were companies that claimed a profitable investment, by promising to costumer dramatically profit in return they got huge volumes of funds from private depositors (Jarvis, 2000). In reality, money gathered was not used for investment but server to pay interest to existing deposits or was transferred abroad to bank account of pyramid organizations. The collapse of pyramid schemes caused an unintimated loss of savings. This situation plunged the country into a deep economic and social crisis. During these years in Albanian market, most of domestic productions had not achieved to be sold, because most of products selling prices were so low that one producer failed to be rewarded for labor costs that he had spent to realize production. Beside this negative side of market for domestic products, it has a positive side for imported products. Unfortunately, the main imports were monopolies related clans associated with the state. Since then, Albania has shown improvements regarding economic development and progress (O’Brien, Nedelkoska, \& Frasheri, 2017).

In the general framework of globalization, we can mention openness of mar- 
kets and trade liberalization. For Albanian producers in order to survive in this globalized market, it needs to be ready for next coming challenges, especially after the signing of free trade agreements with the Balkan countries and beyond. Albanian producers are going through a hard-competitive process and they will pass major challenges that will put into question their existence in the future of commercial sector. Food products, technological and even medicine products, all products are advertised and distributed around the world in order to affect the consumer purchasing decisions. Therefore, consumer is fed up with deceptive advertising of consumer products that are shown as quality products, in fact those products are just stocks from various world countries. Many companies try to sell those products where local production is lower. Although there is a general belief that domestic products are unable to compete for European markets, no one can be sure about the quality of foreign products entering in Albanian market. It seems that also government is not willing to analyze what's going on importing process as long as any goods pay the relevant fees. The only damaged in this case are common Albanian consumers who are deceived from many colorful advertisements and from the fact that those imported products must necessarily be better than locally produced goods. The biggest disadvantage, which currently has to be accepted by Albanian producers regarding exporting their products in foreign markets, is precisely the lack of standards and quality certificates, existing standards does not provide for consumers the image of product quality (O’Brien, Nedelkoska, \& Frasheri, 2017). Standards ISO (International Organization for Standardization) contribute to the development of a global market, open to everyone including countries with lower development.

The Albanian government should support the initiative of some Albanian companies to certify their products and those standards which will help companies to export their products to European Union countries. Working with quality standards increases security and reliability of products. The signing of free trade agreements with countries of the region is also one more incentive for local entrepreneurship to launch the standardization of products and their activity. In the last years The Albanian Parliament has prioritized the adoption of laws that promote the local production and exportation of domestic products. Nowadays many consumers are surprised when they saw in Albanian market fruits, vegetables, meat with the label "domestic production." For consumers this phenomenon has a quick and simple explanation, you have to trust in domestic products they are better than imported ones (Muçaj, 2012).

\subsection{Purpose of Research}

In this research mainly, we will focus on effects of country of origin of products regarding Albanian consumers purchasing process. In addition, we seek the nature of relationship of Albanian consumer ethnocentrism and their perception toward domestic products. In order to understand the nature of the relationships between factors affecting the purchase of foreign products, the following ques- 
tions are addressed in this research:

What is the effect of $\mathrm{COO}$ on Albanian consumers purchasing process?

What is the nature of relationship between consumer ethnocentrism and intention to buy domestic products?

Are Albanian consumers willing to pay more for products from a certain country than for the same products from other countries?

What is the nature of relationship between income, gender, level of education and the effect of country of origin?

What is the nature of relationship between income, gender, level of education and consumer ethnocentrism?

What is the effect of brands clues, price and previous product experience on Albanian consumer regarding their purchasing behavior?

\subsection{Consumer Purchase Behavior}

We live in a consumer society. The role of the consumer is becoming more important, whether as individuals, as groups or organizations. In this case consumers who are facing with purchasing process related to foreign products, they may need different information sources to make a good evaluation regarding purchasing decisions (Hannah \& Baudrillard, 2018). Due to the limited product information, consumers refer to cues either intrinsic such as taste, design or extrinsic such as product $\mathrm{COO}$, price, brand clues to facilitate the process of product evaluation. According to (Schiffman \& Kanuk, 1997) consumer behavior is the action that consumer exhibit in seeking for buying, using, evaluating goods and services that they think will satisfy their needs. Furthermore, consumer behavior tries to understand consumers purchase process by using their accessible resources such as money, time and attempts on buying related goods.

\subsection{Global Product Image}

Nowadays, many factors such as globalization, technological developments and different marketing strategies are affecting consumer behavior. These factors had contributed to make dramatic changes in consumer behavior in the past few decades (Erixon, 2018).

Every day we are bombarded with hundreds of messages from advertisers, trying convincing us for buying their products. Whether we are buying coca or a cell phone we are faced with decisions throughout our daily live. When we want to buy a product in store for example; there are many factors influence our buying decisions such as store promotions, store environment, level of service, price, psychological value of product, past experience and overall retail experience. As consumers we decide to buy the product from many alternatives which we believe will satisfy our needs.

According to (Solomon, 1996) consumer behavior is a dynamic process where individuals select and purchase goods or services and ideas, which satisfies their needs and desires. Most widely excepted definition of consumer behavior given 
by (Belch \& Michael, 2007) is "the process and activities people engage in when searching for, selecting, purchasing, using, evaluating, and disposing of products and services so as to satisfy their needs and desires (p. 105)".

\subsection{The Derived Model}

According to the model of consumer behavior derived from literature review (Hawkins, Best, \& Coney, 1998) as shown in Figure 1, consumer behavior involves several steps. Firstly, we recognize a need; something is not as it should be. After recognizing our need the next step is information search; what alternatives we possess in order to satisfy or need or solve the problem. After this step we try to make an evaluation of alternatives. Finally, we have to decide to make purchasing behavior. All these steps of consuming behavior are affected by cultural, social, individual and psychological factors.

\subsection{Country of Origin}

Nowadays, international trade has increased its business volume. The competition between business organizations has reached its limits. In order to be part of market share many companies are increasing their product quality and are trying to satisfy consumers by all costs. In the same time consumers are faced with different product purchase alternatives, which make difficult their purchasing decisions. Consumers create a country image through direct experience, information from others people and other information related to desired products (Samiee, 1994). The image of country of origin together with others components such as brand clues, product perceived quality and price influence the way that consumer think and behave during product purchasing process (Hamzaoui Essoussi, 2007).

An understanding of consumer purchase tendencies and quality perceptions from products made in different countries is a significant factor affecting and determining marketing strategies (Han, 1996). Furthermore, consumer may behave not in the same manner to all foreign products, or even they may perceive differently products originating from the same country, their opinion about imported goods from one country may show difference when it comes to textile, or

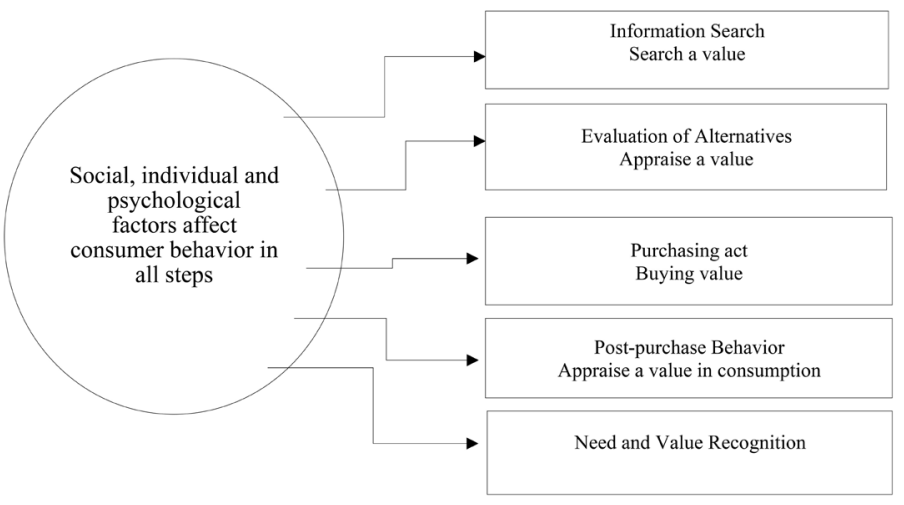

Figure 1. The derived model. 
electronic products, in addition one country may have a rank high for one category of products and low for another different category (Han \& Terpstra, 1988). During purchasing process consumers focus on characteristic of product that fulfills their needs. Consumer past experience is an important factor that affect consumers evaluations of product. However, consumers have tendency to consider as significant also intrinsic cues such as the physical characteristics, packaging taste and extrinsic cues such as made in label (COO) or product brand name (Al-Sulaiti \& Baker, 1998). The existence of extrinsic cues such as COO may contribute to consumer's product evaluation. Market researchers have been interested in how consumers respond to goods from different countries. Therefore, the effect of $\mathrm{COO}$ on consumers' purchasing process has become a study object for scholars from different countries. According to results from past research the image of country of origin has great importance toward consumer product purchasing process, it can affect consumer's perception of product's quality and expected price. During product purchasing process, when high enrolment is needed the effect of country of origin is more decisive (Granzin \& Olsen, 1998). The effect of COO it might be important when consumers do not possess enough knowledge or experience with product. The perception of country of origin is influenced by many factors such as demographics. For instance, female consumer possesses different product attitude compared with male consumers (Johansson \& Nebenzahl, 1987).

\subsection{Consumer Ethnocentrism}

Throughout history, many communities considered knowledge or the transition from one culture to another something disturbing and threatening, therefore they refuse foreign culture by focusing on theirs. This type of reaction to another culture is called ethnocentrism. The concept of ethnocentrism for the first time in academic literature has been used by William Graham Sumner in 1906 as:

"The view of things in which one is own group is the center of everything, and all others are scaled and rated with reference to it ... Each group nourishes its own pride and vanity, boasts itself superior, exalts its own divinities and looks with contempt on outsiders (p. 13)" (Sumner, 1906).

According to ethnocentric concept people see their ethnic group in the center of the universe, moreover they have the tendency to evaluate others differently due to their point of view of social groups, to which they belong to. Ethnocentric people generally accept more easily other people culturally similar to them and have the tendency to deny people different to their ethnic groups (Rosenblatt, 1964; Klein, 2002).

In other researchers' consumers' ethnocentrism found to have a great influence on consumers preferences (Baughn \& Yaprak, 1993). Cultural and social resemblance between countries it may influence the effect of consumer ethnocentric tendencies on attitudes regarding foreign products. According to Shar- 
ma, consumers with level of ethnocentrism believe that buying foreign products affect negatively economic development and increase unemployment. Ethnocentric consumers have two purchasing intentions, firstly they are more likely to choose products originating from their home country, and secondly are likely to have positive purchasing intention other products coming from countries based on their own nationality (Sharma \& Shin, 1995).

Furthermore, when domestic product alternative is not available, consumer with high level ethnocentrism have tendency to purchase products from countries with cultural similarity (Bilkey \& Nes, 1984). Many researches have link level of ethnocentrism to the country of origin effect. For consumers with low level of ethnocentrism most significant factor that affect their purchasing intentions is price, in contrary consumers with high level of ethnocentrism are affected from the product country of origin (Thelen, 2002).

For example, in Russian market the level of consumption of domestic consumer goods higher related to imported ones however when it comes to tangible goods, this tendency is not valuable (Thelen \& Honeycutt, 2006). The basic object of consumer ethnocentrism is product; therefore, consumer ethnocentrism is subject to change on different products categories.

In recent days in order to increase the consumption of domestic products in Albanian market different marketing campaigns supported by government emerged such as "Blej Shqip". Buy made in Albania however the effectiveness is a matter of discussion. To some extent such campaigns contributed to raise the level of positive attitude regarding domestic products however in presence of highly quality foreign products, domestic manufacturers have to do much work in order to make a difference in market (Muçaj, 2012).

\section{Methodology}

\subsection{Study Hypothesis}

Based on the research questions we tend to test the following hypothesis:

$\mathrm{H} 1$. Country of origin has greater influence on Albanian consumers purchase decisions.

$\mathrm{H} 2$ : Consumers with high levels of ethnocentrism will have more positive attitudes toward domestically produced products.

H3: The ethnocentric characteristics of Albanian consumers differ according to their level of education, gender and income level.

\subsection{Research Setting and Sample}

In this study 285 consumers were questioned by questionnaire to find their perception and attitudes to domestically produced goods in relationship with country of origin and consumer ethnocentrism. The survey results from 270 participants were found to be useful for the survey, which is equal to a response rate of $94 \%$ of all sample date. The data was analyzed through SPSS using comparing means, t-test and one-way ANOVA. 


\subsection{Questionnaire Design}

As stated in the introduction, the purpose of the study was to seek the relationship between country of origin, consumer ethnocentrism and attitudes of consumers regarding domestic products purchase preferences. Furthermore, it is tried to investigate the effects of brand name, price and product experience upon Albanian consumers. The study questionnaire consists three parts. The first part consisted demographic questions related to gender, age, education, and income. The second part consisted of questions to identify the effect of country of product origin, price, brand name and product experience on Albanian consumer purchasing intentions. This research tries to identify consumer perception of foreign goods that are originated from specific countries such as: Turkey, Greece and Italy (Table 1).

\subsection{CETSCALE}

The Third part sought to measure Albanian consumer's ethnocentrism. This study was one the first modest attempt trying to analyze consumer ethnocentrism in Albanian market. In this study the 7 -item "CETSCALE" (Shimp \& Sharma, 1987) was used, due to lack other studies in this field, "CETSCALE" which had been translated and adopted to Albanian language. CETSCALE includes a five-point Likert-type scale for responses ( 1 = "Strongly Disagree"; $5=$ "Strongly Agree") (Table 2).

Table 1. Other factors effecting consumer purchase decision.

1 Did you live more than three months in one of the following countries?

2 In general, products manufactured in ___ are qualitative.

3 Usually do not prefer products from

4 I buy products based on my previous experience with these products

5 My choice is usually based on well-known brands products.

6 Price is the main factor that influences my buying.

\section{Table 2. CETSCALE Questions.}

1

Is in the best of Albania setting quotas (limits) for the importation of foreign products, when the same products are produced in Albania.

2 Buying domestic products (Made in Albania) contributes to the economic development of Albania.

3 We need to buy foreign products only when those products are not produced in Albania.

4 We should purchase products manufactured in Albania instead of letting other countries get rich off us.

5 Do you think who does not prefer to buy Albanian products is less patriotic.

If two products were equal in quality, but one was from foreign countries and one was from the Albania, I would pay $10 \%$ more for the product from Albania. 


\section{Results of the Study}

\section{Testing the Hypotheses}

H1. Country of origin has great influence on Albanian consumers purchase decisions

Country of origin is one of the most significant evaluative criteria regarding purchasing behavior. Therefore, $\mathrm{COO}$ affects consumer's intention to buy the product. As shown at Figure 2 Albanian consumers have a strong positive attitude towards Italian products. This positive country image for Italian products will serve as a positive clue for Albanian consumers' attitudes towards products made in that country. Other data from the study shows that preferences of the product country may show differences among consumers who had previous experience with specific country products or had lived for a period time in those specific countries.

The study demonstrates that when a country's product image may be a generally negative, product that comes from those countries are not evaluated favorably. Therefore, due to negative stereotyped country image, products from countries like Greece and Turkey are more in disadvantage in selling in Albanian market compared to Italian products. Therefore, $\mathrm{H} 1$ hypothesis are supported by results of this study. Albanian consumers perceive products brands from Italy as the best compare to products from Turkey and Greece

$\mathrm{H} 2$ : Consumers with high levels of ethnocentrism will have more positive attitudes toward domestically produced products.

Based on the finding of passed researches discussed in literature review, there is a positive relationship between consumer ethnocentrism and intention to buy domestic products. Klein (1998) suggested that consumer with high level of ethnocentrism are associated with more positive beliefs about domestically produced products (Klein, 1998). In addition, they prefer domestic products and they believe that products from their home country are more qualitative compare to other countries. Furthermore, the positive relationship between consumer ethnocentrism and positive believe about quality of domestically produced goods is true for consumers in developed countries (Balabanis \& Diamantopoulos, 2004), in less developing countries this relationship is not supported (Wang \& Lamb, 1983). Hypothesis H2 had proposed that consumer ethnocentrism is positively related to consumers' intentions to purchase domestically produced products. The results of this study showed in table supported the existence of positive relationship between consumer ethnocentrism and intention to buy domestic products (Table 3 ).

Therefore, the proposed hypothesis H2: Individuals with high levels of consumer ethnocentrism will have more favorable attitudes toward domestic products, is supported.

H3. The ethnocentric characteristics of Albanian consumers differ according to their level of education, gender and income level. 


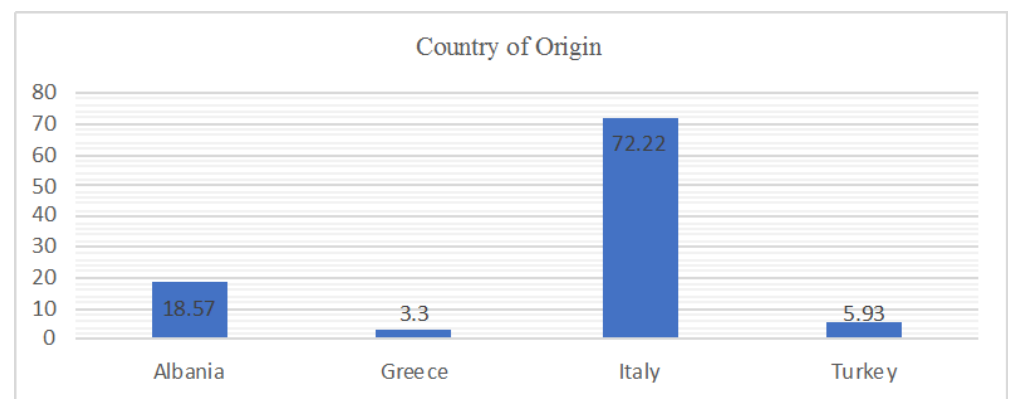

Figure 2. Perception of country of origin.

Table 3. Attitudes toward domestically produced products.

Questions value: 1 Strongly Disagree, 2 Disagree, 3 Neutral, 4 Agree, 5 Strongly Agree

\begin{tabular}{|c|c|c|c|c|}
\hline $\begin{array}{l}\text { CETSCALE questions measuring consumer } \\
\text { ethnocentrism }\end{array}$ & $\mathrm{N}$ & Mean & Std. Dev & Chi-Square \\
\hline $\begin{array}{l}\text { 1) Is in the best of Albania setting quotas (limits) for } \\
\text { the importation of foreign products, when the same } \\
\text { products are produced in Albania. }\end{array}$ & 267 & 3.92 & 1.210 & $139.685 a$ \\
\hline $\begin{array}{l}\text { 2) Buying domestic products (Made in Albania) } \\
\text { contributes to the economic development of Albania }\end{array}$ & 270 & 4.24 & 1.005 & $241.296 \mathrm{~b}$ \\
\hline $\begin{array}{l}\text { 3) We need to buy foreign products only when those } \\
\text { products are not produced in Albania }\end{array}$ & 268 & 3.59 & 1.252 & $84.761 \mathrm{c}$ \\
\hline $\begin{array}{l}\text { 4) We should purchase products manufactured in } \\
\text { Albania instead of letting other countries get rich off us. }\end{array}$ & 263 & 3.11 & 1.400 & $29.605 d$ \\
\hline $\begin{array}{l}\text { 5) Do you think who does not prefer to buy Albanian } \\
\text { products is less patriotic }\end{array}$ & 270 & 2.23 & 1.221 & $99.630 \mathrm{~b}$ \\
\hline
\end{tabular}

According to (Han, 1996; Sharma \& Shin, 1995) females tend to be more conservative, less individualistic, in addition it is suggested that females have high ethnocentric levels compare to males. No significant results were found in level of ethnocentrism between women and males. Therefore, hypothesis $\mathrm{H} 3$ which suggest that consumer's ethnocentrism is different on base of gender was not supported by finding of this study. People with a higher level of education tend to have less ethnocentric tendencies. In addition, other researches did not find any differences in ethnocentric tendencies between consumers with different levels of education (Keillor, 2001).

According to results of this study, there is a positive link between high level of education and ethnocentric tendencies. However, respondents who had postgraduate degrees had the least ethnocentric tendencies. In spite of finding ethnocentric tendencies in Albanian consumers when it comes to finalize the purchasing behavior they are not affected from their ethnocentric tendencies. Therefore, the following hypothesis H3 is not fully supported.

Several studies have suggested that consumers with higher levels of social status have fewer ethnocentric tendencies compared to consumers with lower levels of social status (Sharma \& Shin, 1995). 
In contrary to studies that found positive relationship between higher level of income and exhibiting higher level of ethnocentrism, in the present study no significant evidence was found between level of income and consumer ethnocentrism. Therefore, the following hypothesis $\mathrm{H} 3$ that suggest individuals with different level of income have different level of consumer ethnocentric tendencies is not supported by the results of this study (Table 4).

\section{Conclusion and Recommendations}

\subsection{Discussion}

The purpose of this study was to examine the nature of relationship between ethnocentrism and purchasing domestic products and the effect of country of origin on purchasing intention of Albanian consumers. Majority of the Albanian consumers give equal importance to brand clues, price and COO. Therefore, it can be said that that consumers have the tendency to be conscious about their purchase decisions. In addition, they own information from specific brands and they have different country image products, when making a purchase decision they consider brand clues, previous product experience, price and other factors as well. The study demonstrates that both positive and negative knowledge of country of origin has a great importance in consumer purchasing behavior, and also this knowledge has important effect on consumers beliefs towards goods made in that country. Therefore, in order to increase sells of imported goods in Albanian markets, firms which want to enter in Albanian market have to consider Albanian consumers attitude towards country of origin. In addition, they have to examine product segmentation in accordance with effect of the different demographic variables, gender, age, education, income, because those variables have significant causes of variance in perception of countries of origin. As it is widely expected, consumers do not use country of origin as only criteria in purchasing behavior, but together with product extrinsic and intrinsic characteristic they evaluate the country image product.

The results of the research to some extent supported the existence of positive relationship between consumer ethnocentrism and intention to buy domestic goods. Those consumers' ethnocentric tendencies show differences towards consumer education level. Therefore, market segmentation of consumers with high level education is important for promoting Albanian products. In contrary to studies that found positive relationship between higher level of income and exhibiting higher level of ethnocentrism, in the present study no significant evidence was found between level of income and consumer ethnocentrism. Albanian consumers who have ethnocentric tendencies have a positive attitude toward domestically produced product, but they do not consider as less patriotic individuals who do not prefer purchasing domestic products. As in important factor regarding consumer purchase decisions, ethnocentric tendencies should be taken into consideration form domestic firms when promoting their products in domestic market. 
Table 4. Testing relationship between education and ethnocentrism.

\begin{tabular}{|c|c|c|c|c|}
\hline & $\mathrm{df}$ & Mean Square & F & Sig. \\
\hline \multirow{3}{*}{$\begin{array}{l}\text { 1) Is in the best of Albania setting quotas (limits) } \\
\text { for the importation of foreign products, } \\
\text { when the same products are produced in Albania. }\end{array}$} & 3 & 9.173 & 6.638 & 0.000 \\
\hline & 261 & 1.382 & & \\
\hline & 264 & & & \\
\hline \multirow{3}{*}{$\begin{array}{l}\text { 2) Buying domestic products (Made in Albania) } \\
\text { contributes to the economic development of Albania }\end{array}$} & 3 & 7.355 & 7.809 & 0.000 \\
\hline & 264 & 0.942 & & \\
\hline & 267 & & & \\
\hline \multirow{3}{*}{$\begin{array}{l}\text { 3) We need to buy foreign products only when } \\
\text { those products are not produced in Albania }\end{array}$} & 3 & 9.304 & 6.273 & 0.000 \\
\hline & 262 & 1.483 & & \\
\hline & 265 & & & \\
\hline \multirow{3}{*}{$\begin{array}{l}\text { 4) We should purchase products manufactured in } \\
\text { Albania instead of letting other countries get rich off us. }\end{array}$} & 3 & 14.164 & 7.750 & 0.000 \\
\hline & 257 & 1.828 & & \\
\hline & 260 & & & \\
\hline \multirow{3}{*}{$\begin{array}{l}\text { 5) Do you think who does not prefer to buy Albanian } \\
\text { products is less patriotic }\end{array}$} & 3 & 2.307 & 1.581 & 0.194 \\
\hline & 264 & 1.459 & & \\
\hline & 267 & & & \\
\hline \multirow{3}{*}{$\begin{array}{l}\text { 6) If two products were equal in quality, but one was } \\
\text { from foreign countries and one was from the Albania, } \\
\text { I would pay } 10 \% \text { more for the product from Albania }\end{array}$} & 3 & 0.362 & 0.200 & 0.897 \\
\hline & 258 & 1.814 & & \\
\hline & 261 & & & \\
\hline
\end{tabular}

\subsection{Limitations and Future Research}

In the study, all respondents were conducted from internet, mainly young individuals from middle or upper class; therefore, the results cannot be generalized to different Albanian society classes. Another limitation of this study was using product in general. This made difficult generalization of result to different product categories. Future researches should take in consideration to study different types of products, because country of origin may vary across different product categories. Also, it should be taken in consideration purchasing intention of Albanian consumer when they are faced with products which need low involvement and high involvement. In this study, the influence of ethnocentrism on evaluation of goods in different product categories was not examined, and future research should take this influence on consideration and investigate its effects. In this study, we deal with only Albanian consumers in Albanian market. In future researches, we should take into consideration also Albanian consumers in Kosovo and Macedonian market. Therefore, generalizability of results of this study should be limited only to Albanian consumer living in Albania.

\section{Conflicts of Interest}

The author declares no conflicts of interest regarding the publication of this paper. 


\section{References}

Ahmed, S. A., \& D'Astous, A. (1993). Cross-National Evaluating of Made-In Concept Using Multiple Cues. European Journal of Marketing, 27, 39-52. https://doi.org/10.1108/03090569310040343

Alexandra, E., \& Mazzocchi, M. (2007). Domestically Produced Food: Consumer Perceptions of Origin, Safety and the Issue of Trust. Acta Agriculturae Scandinavica, Section C: Food Economics, 4, 3-12. https://doi.org/10.1080/16507540701192485

Al-Sulaiti, K. I., \& Baker, M. J. (1998). Country of Origin Effects: A Literature Review. Marketing Intelligence and Planning, 16, 150-199. https://doi.org/10.1108/02634509810217309

Balabanis, G., \& Diamantopoulos, A. (2004). Domestic Country Bias, Country-of-Origin Effects, and Consumer Ethnocentrism: A Multidimensional Unfolding Approach. Journal of the Academy of Marketing Science, 32, 80-95. https://doi.org/10.1177/0092070303257644

Baughn, C. C., \& Yaprak, A. (1993). Mapping Country-of-Origin Research: Recent Developments and Emerging Avenues. In N. Papadopoulos, \& L. Heslop (Eds.), Product Country Images: Impact and Role in International Marketing (pp. 89-115). New York: Haworth Press.

Belch, G., \& Michael, B. (2007). Advertising and Promotion: An Integrated Marketing Communications Perspective. New York: McGraw-Hill.

Bilkey, W., \& Nes, E. (1984). Country of Origin Effects on Product Evaluations. Journal of International Business Studies, 13, 89-100. https://doi.org/10.1057/palgrave.jibs.8490539

Doka, D. (2005). Socio-Economic and Regional Developments of Albania after 1999. Geographical Studies.

Erixon, F. (2018). The Economic Benefits of Globalization for Business and Consumers. https://ecipe.org/wp-content/uploads/2018/01/Globalization-paper-final.pdf

Granzin, K. L., \& Olsen, J. E. (1998). Americans' Choice of Domestic over Foreign Products, a Matter of Helping Behavior? Journal of Business Research, 43, 39-54. https://doi.org/10.1016/S0148-2963(97)00101-X

Hamzaoui Essoussi, L. (2007). Consumers' Product Evaluations in Emerging Markets: Does Country of Design, Country of Manufacture, or Brand Image Matter? International Marketing Review, 24, 409-426. https://doi.org/10.1108/02651330710760991

Han, C. (1996). Testing the Role of Country Image in Consumer Choice Behaviour. European Journal of Marketing, 24, 24-39. https://doi.org/10.1108/EUM0000000000609

Han, C., \& Terpstra, V. (1988). Country-of-Origin Effects for Uni-National and Bi-National Products. Journal of International Business Studies, 19, 235-255. https://doi.org/10.1057/palgrave.jibs.8490379

Hannah, A., \& Baudrillard, J. (2018). Pedagogy in the Consumer Society. https://infed.org/mobi/hannah-arendt-and-jean-baudrillard-pedagogy-in-the-consume r-society/

Hawkins, I., Best, R. J., \& Coney, K. A. (1998). Consumer Behavior: Building Marketing Strategy. New York: McGraw-Hill.

Jarvis, C. (2000). The Rise and Fall of Albania's Pyramid Schemes. Finance and Development, 37 .

Johansson, J. K., \& Nebenzahl, I. D. (1987). Country-of-Origin, Social Norms and Behavioral Intention. Advances in International Marketing, 2, 65-79. 
Keillor, B D. (2001). Global Consumer Tendencies. Psychology and Marketing, 18, 1-19. https://doi.org/10.1002/1520-6793(200101)18:1<1::AID-MAR1>3.0.CO;2-U

Klein, J. (1998). The Animosity Model of Foreign Product Purchase: An Empirical Test in the People's Republic of China. Journal of Marketing, 62, 89-100. https://doi.org/10.1177/002224299806200108

Klein, J. G. (2002). Us versus Them, or Us versus Everyone? Delineating Consumer Aversion to Foreign Goods. Journal of International Business Studies, 33, 345-363. https://doi.org/10.1057/palgrave.jibs.8491020

Muçaj, A. (2012). Nisma “Blej Shqip”. Monitor. https://www.monitor.al/nisma-blej-shqip

O'Brien, T., Nedelkoska, L., \& Frasheri, E. (2017). What Is the Binding Constraint to Growth in Albania? https://growthlab.cid.harvard.edu/files/growthlab/files/alb_growth_diagnostic_report.p df

Rosenblatt, P. C. (1964). Origins and Effects of Group Ethnocentrism and Nationalism. Journal of Conflict Resolution, 8, 131-146. https://doi.org/10.1177/002200276400800204

Samiee, S. (1994). Customer Evaluation of Products in Global Markets. Journal of International Business Studies, 25, 579-604. https://doi.org/10.1057/palgrave.jibs.8490213

Schiffman, L. G., \& Kanuk, L. L. (1997). Consumer Behavior. Upper Saddle River, NJ: Prentice Hall.

Sharma, S., \& Shin, J. (1995). Consumer Ethnocentrism: A Test of Antecedents and Moderators. Journal of the Academy of Marketing Science, 23, 26-37. https://doi.org/10.1007/BF02894609

Shimp, T., \& Sharma, S. (1987). Consumer Ethnocentrism: Construction and Validation of the CETSCALE. Journal of Marketing Research, 24, 280-289. https://doi.org/10.1177/002224378702400304

Solomon, M. R. (1996). Consumer Behavior: Buying, Having, and Being (3rd ed.). Englewood Cliffs, NJ: Prentice Hall.

Sumner, W. G. (1906). Folkways: The Sociological Importance of Usages, Manners, Customs, Mores, and Morals. New York: Ginn \& Co.

Thelen, S. (2002). Antecedents and Consequences of Consumer Ethnocentrism across Russia's Three Sub-Cultures. Doctoral Dissertation, Norfolk, VA: Old Dominion University.

Thelen, S., \& Honeycutt, J. E. D. (2006). The Impact of Regional Affiliation on Consumer Perceptions of Relationships among Behavioral Constructs. Journal of Business Research, 59, 965-973. https://doi.org/10.1016/j.jbusres.2006.03.007

Wang, C., \& Lamb, C. (1983). The Impact of Selected Environmental Forces upon Consumers' Willingness to Buy Foreign Products. Journal of the Academy of Marketing Science, 11, 71-84. https://doi.org/10.1007/BF02721862 